\title{
BIOSTRATIGRAPHY OF THE UPPER DEVONIAN KHOSHYEILAGH FORMATION IN NE IRAN BASED ON CONODONTS AND OTHER FAUNAS
}

\author{
FATEMEH JAFARBEIGLOO (D) \\ Department of Earth Sciences, Science and Research Branch, Islamic Azad University, Tehran, Iran. \\ fatemehjafarbeigloo@srbiau.ac.ir,mehranarian@srbiau.ac.ir
}

MAHMOUDREZA MAJIDIFARD (1), BAHAEDDIN HAMDI (1)

Research Institute for Earth Science, Geological Survey of Iran, Meraj Blvd, Azadi Sq, P.O. Box 13185-1494, Tehran, Iran. m_majidifard@yahoo.com,majidifard@ries.ac.ir,hamdibahaeddin@gmail.com

AFSHIN ASGHARI (D)

National Iranian Oil Company, Seoul St., Sheikh Bahaei Sq, Tehran, Iran. afshin_asghari@yahoo.com

MEHRAN ARIAN

Department of Earth Sciences, Science and Research Branch, Islamic Azad University, Tehran, Iran. mehranarian@srbiau.ac.ir

\begin{abstract}
The Khoshyeilagh Formation located in the northeast of Iran yielded seven conodont species and sub-species and 19 macroand microfossil taxa that allow recognition of two conodont biozones and one biozone based on calcareous microfossils. The latest Frasnian age (the Upper rhenana to linguiformis zones) is attributed to the topmost strata with Icriodus alternatus. Its replacement with I. cornutus indicates the Famennian (Lower triangularis to Lower crepida zones) corresponding to the Umbellina Zone. The fossil assemblages identified in the Khoshyeilagh Formation represent a shallow marine environment with a tropical climate at the time of deposition. The fossil species from the Khoshyeilagh Formation and the sedimentary basins in Algeria, Libya, Morocco, Poland, and Russia reveal a close connection between the Iranian plateau and the northern parts of Gondwana in the Late Devonian. The biofacies and lithofacies analyses show a sea level decline at the end of Frasnian, followed by a considerable sea level drop, as in other regions of the world. After a short time, in the Famennian, the deepening occurred in some parts of the area and the open marine facies (bioclast spicule wackestone-packstone) were deposited. This study is the first attempt to determine Frasnian-Famennian boundary based on conodont assemblages and other fossil species such as umbellulids, tentaculites, and ostracods. The distribution of these species is interpreted in sedimentological, stratigraphic, sequence stratigraphy, and the global eustatic context.
\end{abstract}

Keywords: biofacies, conodont, Frasnian-Famennian boundary, Late Devonian, NE Iran.

RESUMO - A Formação Khoshyeilagh, localizada no nordeste do Irã, produziu sete espécies de conodontes e subespécies e 19 táxons de macro- e microfósseis, o que permite o reconhecimento de duas biozonas de conodontes e uma biozona baseada nos microfósseis calcáreos. A idade Frasniana mais superior (as zonas superiores rhenana a linguiformis) é atribuída ao estrato mais superior com Icriodus alternatus. A sua substituição por I. cornutus indica o Famenniano (zonas iniciais triangularis superior a crepida superior), correspondendo à Zona de Umbellina. Os fósseis identificados na Formação Khoshyeilagh representam um ambiente marinho raso, com um clima tropical, no momento de deposição. As espécies fósseis da Formação Khoshyeilagh e as bacias sedimentares na Argélia, Líbia, Marrocos, Polônia e Rússia revelam uma conexão íntima entre o platô iraniano e as partes norte do Gondwana no Neodevoniano. As biofácies e litofácies analisadas mostram um declínio do nível do mar no final do Frasniano, seguido por uma considerável queda do nível do mar, como em outras regiões do mundo. Após um curto tempo, no Famenniano, o aprofundamento ocorreu em algumas partes da área, e a fácies marinha aberta (bioclast spicule wackestone-packstone) foi depositada. Este estudo é a primeira tentativa de determinar o limite Frasniano-Famenniano com base em associações de conodontes e outras espécies fósseis, como umbellulídeos, tentaculites e ostracodes. A distribuição dessas espécies é interpretada nos contextos sedimentológico, estratigráfico, de estratigrafia de sequências e de eustasia global.

Palavras-chave: biofácies, conodonte, limite Frasniano-Famenniano, Neodevoniano, NE Irã. 


\section{INTRODUCTION}

Comprehensive stratigraphic investigations carried out in the Khoshyeilagh Formation (northeastern Iran) by Bozorgnia (1973) resulted in its subdivision into six parts at the type section, based on paleontological evidence. Later, Brice et $a l$. (1974) studied the brachiopods of the area and proposed the Late Devonian age for this formation. Ahmadzadeh Heravi (1982) studied the brachiopods and conodonts of the Khoshyeilagh Formation and recognized an Early to Late Devonian age. Hamdi \& Janvier (1981) measured the thickness of this formation as $1510 \mathrm{~m}$ and determined the age as Early to Late Devonian. Another study evaluated the boundary of Frasnian-Famennian in the Khoshyeilagh Formation using the rare conodont assemblages and other fossil species (Wendt et al., 2002). Ghavidel-Syooki \& Owens (2007) determined the Late Devonian age for the Khoshyeilagh Formation by studying the palynomorphs in the Kuhe Ozon section. They estimated a warm tropical climate and a shallow environment at the time of deposition. Weddige (1984a, b) studied the conodonts of this formation and identified the upper Eifelian to Givetian in the lower part. Ashouri (2006) reported six new species of conodonts in the type section of the Khoshyeilagh Formation and proposed Eifelian to Tournaisian age for this unit.

\section{GEOLOGY}

Based on the geological structural zoning of Iran (Figure 1A), one part of the study area is located in the Koppeh Dagh sedimentary basin (Stocklin, 1968) and the other part belongs to the Eastern Alborz structural zone (Binalud Zone) (Nabavi, 1976). Kuhe Ozon and Pelmis stratigraphic sections with clastic-carbonate nature show similarities to the Eastern Alborz structural zone. The Robat-e Qarehbil section is placed in the Koppeh Dagh basin (Stocklin, 1968), located in the southern margin of this zone. The Sefid-Dali main fault separates these two structural zones and represents a thrust zone in which the Koppeh Dagh zone has been thrusted over the Eastern Alborz zone.

Because of some differences between lithological facies in coeval rock units, the study area can be divided into two structural zones. The presence of Devonian shale and carbonate facies (Khoshyeilagh Formation) in the Kuhe Ozon and Pelmis sections show their similarity to the Eastern Alborz zone (Figure 1B). They represent the same depositional environments during the Devonian and Carboniferous. Regarding the observed lithological and age similarities of the Khoshyeilagh Formation in Koppeh Dagh and Binaloud zones, the Kuhe Ozon and Pelmis sections are considered as parts of the Eastern Alborz structural zone.

Three studied stratigraphic sections are located around Bojnurd and Jajarm cities in the northeastern part of Iran (Figure 1C). The geological maps for Gardaneh-e Pelmis, Kuhe Uzon, and Robat-e Qarehbil were prepared as Bojnurd, Sankhast, and Robat-e Qarehbil sheets, respectively.

\section{METHOD OF THE INVESTIGATION}

In order to study the Khoshyeilagh Formation in the northeastern part of Iran, three main sections including Pelmis, Robat-e Qarehbil, and Kuhe Ozon were selected. The geological maps of these areas were prepared, and samples were collected. During the field work, the sedimentary structures and textures were evaluated and recorded, the grain size was measured, the skeletal and trace fossils were recorded, and the horizontal and vertical relationship of the facies and the geometric properties of the layers were assessed.

Nearly 460 samples were collected for thin section and microscopic studies, 59 samples from limestone units (i.e. 17 samples from Pelmis section, 19 samples from Robat-e Qarehbil section, and 23 samples from Kuhe Ozon section) were taken for conodont studies. All these 59 samples were crushed, leached by acid, and placed inside $20 \%$ acetic acid buffer solution for four days. After dissolution, the obtained sediments were passed through 60, 150, and 200 mesh sieves and washed down. The ramiform elements and the other microfossils (the fish remains, ostracods, brachiopods, and gastropods) were collected from washed samples, and identified using an optical microscope. Photos were taken using a scanning electron microscope (SEM; Leo 1450VP) in the laboratory of National Iranian Oil Company (NIOC).

\section{RESULTS AND DISCUSSION}

A sea level transgression occurred in the mid Devonian such that carbonates were deposited in some parts of the Iranian plateau continuously until the Early Carboniferous. In the study area, the Devonian sedimentary sequences are represented from the Eifelian to Famennian (Aqanbati, 2007).

Conodonts are the Devonian guide fossils of worldwide ranges. The sea level and distance from coastlines are two crucial factors controlling their distribution. Low diversity conodont assemblages occur in nearshore settings that often contain endemic species. The stable conditions of the offshore settings are characterized by a high variety of conodont species with global distribution (McGhee, 2001). Most of the studies performed in the Khoshyeilagh Formation reported brachiopods and the palynomorphs at the type section of the formation whereas the conodont and other faunas have been studied rarely. Therefore, the present study is focused on the microfossils. A dense sampling of the studied sections is assessed to identify the standard biozones. Eventually, these biozones are compared with other Devonian sections in Iran.

\section{Lithostratigraphy}

The Upper Devonian deposits of the Robat-e Qarehbil, Kuhe Ozon, and Gardaneh Pelmis sections consist of clastic and carbonate sequences of the Khoshyeilagh Formation. In the Pelmis section (Figure 2), the thickness of the formation, which mainly consists of thick to very thick pale goldenrod colored sandstones, limestones, and dolomitic limestones and light to dark gray medium layered dolomites with marl, shale, 
and siltstone interlayers, is $182 \mathrm{~m}$. The transition from the Padeha Formation to the Khoshyeilagh Formation is gradual whereas a sedimentary gap separates the Khoshyeilagh from the Shemshak Formation that is $260 \mathrm{~m}$ thick in the Robat-e Qarehbil type section (Figure 3). The presence of fireclay and bauxite deposits indicate the lack of sedimentation, and the Permian deposits discordantly cover the Devonian ones. This is the hiatus that has been reported from many parts of the Iranian platform as the Hercynian discontinuity (Wendt et al., 2002), corresponding to the initiation of the Hercynian orogeny (Berberian \& King, 1981). More likely the lack of deposit is connected with the Gondwana glaciation.

In the Kuhe Ozon section (Figure 4), the thickness of the Khoshyeilagh Formation is $436 \mathrm{~m}$. It overlies there the clastic Padeha Formation. The lower boundary is on the top of red color limonitic siltstones of the Padeha Formation. The upper boundary between the Khoshyeilagh and Mobarak Formation is continuous and concordant. In this location, the formation mainly consists of limestones and shales (Supplement 1).

\section{The determination of facies, depositional environment, and sequence stratigraphy}

Based on the facies analysis of the Khoshyeilagh Formation, three clastic facies, 11 carbonate facies, and one hybrid facies were identified. The vertical and lateral changes of the Khoshyeilagh Formation show a shoreface marine depositional environment that begins with alluvial sediments and continues by marine sedimentation. According to these changes, a homoclinal ramp model has been proposed (Jafarbeigloo et al., 2020). This ramp model shows a relatively gentle slope that continues to the basin and is similar to present-day carbonate ramps, like the southern coast of the Persian Gulf and Shark Bay in Australia. This depositional model consists of five sub-environmental units including shoreface, tidal flat, lagoon, shoal, and open marine. The sequence stratigraphic analysis and depositional model evaluations led to the identification of two complete thirdorder sequences, which are limited by discontinuities as a result of sea level changes at the base and top of the sequence, and an incomplete sedimentary sequence at the end of the studied section. The transgressive systems tract (TST) in this sequence is mainly composed of shoal and open marine facies, the maximum flooding surface (MFS) is identified by the bioclast wackestone facies, and the highstand systems tract (HST) mainly consists of lagoon, tidal flat, and shoreface facies. The lithofacies analyses and their interpretations represent a decrease of depth at the end of Frasnian which is followed by major sea level drop similar to other localities at this time. After a period of time and during Famennian, the sea level rose, and the open marine facies (bioclast spicule wackestone-packstone) were deposited. With regard to the identified biozone, Late Devonian age (late Frasnian-early Famennian) is obvious for the Khoshyeilagh Formation.

\section{Biostratigraphy of the studied sections}

Of the 59 samples from the study areas, 12 samples contained conodonts assigned to seven species and subspecies belonging to two genera. The conodonts were recognized using the atlas of conodonts (Ziegler, 1975, 1981) and biozonation was performed based on the studies of Sweet (1988), Ziegler \& Sandberg (1990, 2000), and Bultynck (2007). Although no biostratigraphically diagnostic Palmatolepis specimens have been found, two biozones were identified, based on shallow-water species of Icriodus and Polygnathus. The most important and dominant fossils in the study area include ostracods, brachiopods, tentaculites, and umbellinids. Six genera of umbellinids, three genera of brachiopods, two genera of tentaculites and stylionilinids, and three genera of ostracods were also recognized. Bozorgnia (1973) introduced the Umbellina zone of late Frasnian to early Famennian age. The identified fossil species were compared with the results of previous studies in central and northwestern parts of Iran (Ashouri, 2002, 2004; Gholamalian, 2006, 2007; Gholamalian \& Kebriaei, 2008; Bahrami et al., 2011a, 2011b, 2013; Gholamalian et al., 2011, 2013) and northwest of Iran (Abbasi et al., 2015). The results showed congruency of different sources of evidence (Supplement 2, 3, and 4).

\section{Conodont Biostratigraphy}

Pelmis section:

A total of 17 samples (F.J.B 33 to F.J.B 35) were collected from the limestone and dolomitic $15 \mathrm{~m}$-thick unit in the Pelmis section. Five species and subspecies of Icriodus and Polygnathus were identified: I. alternatus alternatus, I. expansus, I. sp., $P$. praepolitus, and $P$. sp. They probably represent the Upper rhenana-linguiformis zones of the uppermost Frasnian based on the Ji \& Ziegler (1993) age ranges. The Frasnian age is inferred from the lack of Icriodus cornutus (Figure 2, Table 1).

Robat-e Qarehbil section:

A total of 19 samples (F.J.B 48, F.J.B 49, and F.J.B 56) were collected from the $80 \mathrm{~m}$-thick layer limestone with thin layers of siltstone and dolomite part of the Robat-e Qarehbil section. Four species and subspecies were identified, namely Icriodus expansus, I. alternatus alternatus, I. symmetricus, I. sp., Polygnathus sp., and P. praepolitus.

The lower boundary of this zone is known with the first appearance of Icriodus alternatus alternatus and the upper boundary is characterized by the presence of Ctenopolygnathus and Polygnathus praepolitus, which corresponds with the rhenana-linguiformis biozones introduced by Dzik (2002). Based on the presence of Ctenopolygnathus and the lack of Icriodus cornatus, the age of this biozone is late Frasnian (Figure 3).

The Lower rhenana-Upper rhenana biozone can be proposed for this unit but the presence of Polygnathus xylus xylus suggests a younger age (rhenana-linguiformis) (Ji \& Zeigler, 1993; Ziegler \& Sandberg, 2000; Ovnatanova \& Kononova, 2001). Moreover, the occurrence of Icriodus symetricus in sample F.J.B 49 restricts the possible age range to the late Frasnian Upper rhenana Zone (Bahrami et al., 2014). Based on Ji \& Ziegler (1993) the lower boundary of the zone is marked by the appearance of I. a. alternatus while its upper boundary is at the disappearance of $P . x . x y l u s$ and P. praepolitus (Figure 3). 
Table 1. The frequency of conodont species identified in the studied sections.

\begin{tabular}{|c|c|c|c|c|c|c|c|c|c|c|}
\hline Conodont Zones & \multicolumn{8}{|c|}{ Upper rhenana-linguiformis } & \multicolumn{2}{|c|}{$\begin{array}{l}\text { Lower triangularis-Lower } \\
\text { crepida }\end{array}$} \\
\hline Species & $\begin{array}{l}m \\
\stackrel{m}{\longrightarrow}\end{array}$ & 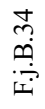 & 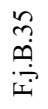 & 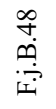 & $\begin{array}{l}\stackrel{g}{+} \\
\stackrel{\leftrightarrow}{-}\end{array}$ & 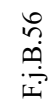 & $\stackrel{\infty}{\dot{m}}$ & $\begin{array}{l}\stackrel{0}{\infty} \\
\stackrel{\varphi}{\longrightarrow}\end{array}$ & $\frac{\stackrel{\sim}{a}}{\stackrel{\oplus}{\rightarrow}}$ & $\frac{n}{\stackrel{n}{m}}$ \\
\hline Icriodus alternatus alternatus & & & 2 & 1 & 3 & & 2 & & 2 & \\
\hline Icriodus expansus & 5 & & & & 1 & & 2 & & & \\
\hline Icriodus sp. & 3 & 3 & 3 & & 5 & & & & 6 & \\
\hline Polygnathus praepolitus & 2 & 1 & 1 & 5 & & 5 & & & 1 & 1 \\
\hline Polygnathus sp. & 2 & 2 & 3 & & 2 & & & & 1 & 2 \\
\hline Icriodus symmetricus & & & & & 1 & & & & & \\
\hline Polygnathus xylus xylus & & & & 2 & & 2 & & & & \\
\hline Icriodus brevis & & & & & & & 1 & & & \\
\hline Icriodus cornutus & & & & & & & & & 5 & \\
\hline
\end{tabular}

Kuhe Ozon section:

A total number of 23 samples (F.J.B 8, F.J.B 10, and F.J.B 12) from Kuhe Ozon section. Two genera and five species and subspecies were recognized. Overall, this section was divided into two biozones.

Zone 1 (probably corresponding to the upper Frasnian Lower rhenana to Upper rhenana zones) covers $80 \mathrm{~m}$ thick succession of shale, sandstone, and limestone. It begins with the appearance of Icriodus brevis and I. alternatus alternatus and ends with the first appearance of I. cornutus (Figure 4).

Zone 2 (probably corresponding to the lower Famennian Middle triangularis to Lower crepida Zones) covers $70 \mathrm{~m}$ thick succession of limestone and dolomite and includes samples F.J.B 12 and F.J.B 15 taken from near the top of the Khoshyeilagh Formation. This biozone is characterized by Icriodus cornutus associated with Polygnatus praepolitus, $P$. sp. A, and Icriodus sp. The lower boundary of this biozone is marked by the appearence of Icriodus cornutus that may indicate the Middle triangularis biozone and the upper boundary is marked by Polygnatus praepolitus (Sandberg \& Dreesen 1984; Ziegler \& Sandberg, 2000; Bultynck,, 2003). The boundary between Frasnian and Famennian is there conformable and continuous (Figure 4).

The correlation of conodont biozones of the studied sections:

The Upper rhenana to linguiformis zones biointerval was recognized in all three studied sections and their conodont species contents are almost the same (Supplement 5). The Lower triangularis to Lower crepida zones interval was identified just in the Kuhe Ozon section. This part of the Khoshyeilagh Formation in the Robat-e Qarehbil section has not yielded conodonts. Based on stratigraphic position, it is assumed to be lower Famennian. It is possible that during the Famennian the Pelmis area was above the sea level and the younger strata are missing. The presence of the Icrioduspolygnathid facies in the studied areas indicates shallowing of the sedimentary basin near the Frasnian-Famennian boundary. At the beginning of the Famennian, the carbonate platform emerged completely. Later in the Famennian, in result of the global sea level drop (Sandberg et al., 1988), the marine bioclast spicule wackestone-packstone facies entered. The data presented here support the hypothesis of Afshar-Harb (1979) that the Devonian regression in Iran expanded from the northeast toward the southwest.

Umbellinas

Umbellinas (Loeblich \& Tappan 1961 replaced the name Umbella with Umbellina) are bottle-shaped or spherical microfossils of Devonian to Mississippian age. These microfossils have been distributed along vast areas in Europe, Asia, Australia, and North America. Some kinds of umbellinas were attributed to foraminifers because of their radial symmetry (Bykova \& Polenova, 1955) but others were attributed to the Charophyta algae (Peck, 1974; Doweld, 2014) or classified as microproblematics by Peck (1974). Mamet (1970) pointed out that umbellinas are found frequently in restricted and hypersaline environments. This was the main reason for including them into the Charophyta. The shell diameter of these fossils ranges from 50 to $400 \mu \mathrm{m}$ (Flügel, 2010). Their occurrence is limited to shallow sublittoral facies, where the salinity is increased. Umbellinas are rarely found together with foraminifers (Flügel, 2010). Their presence 

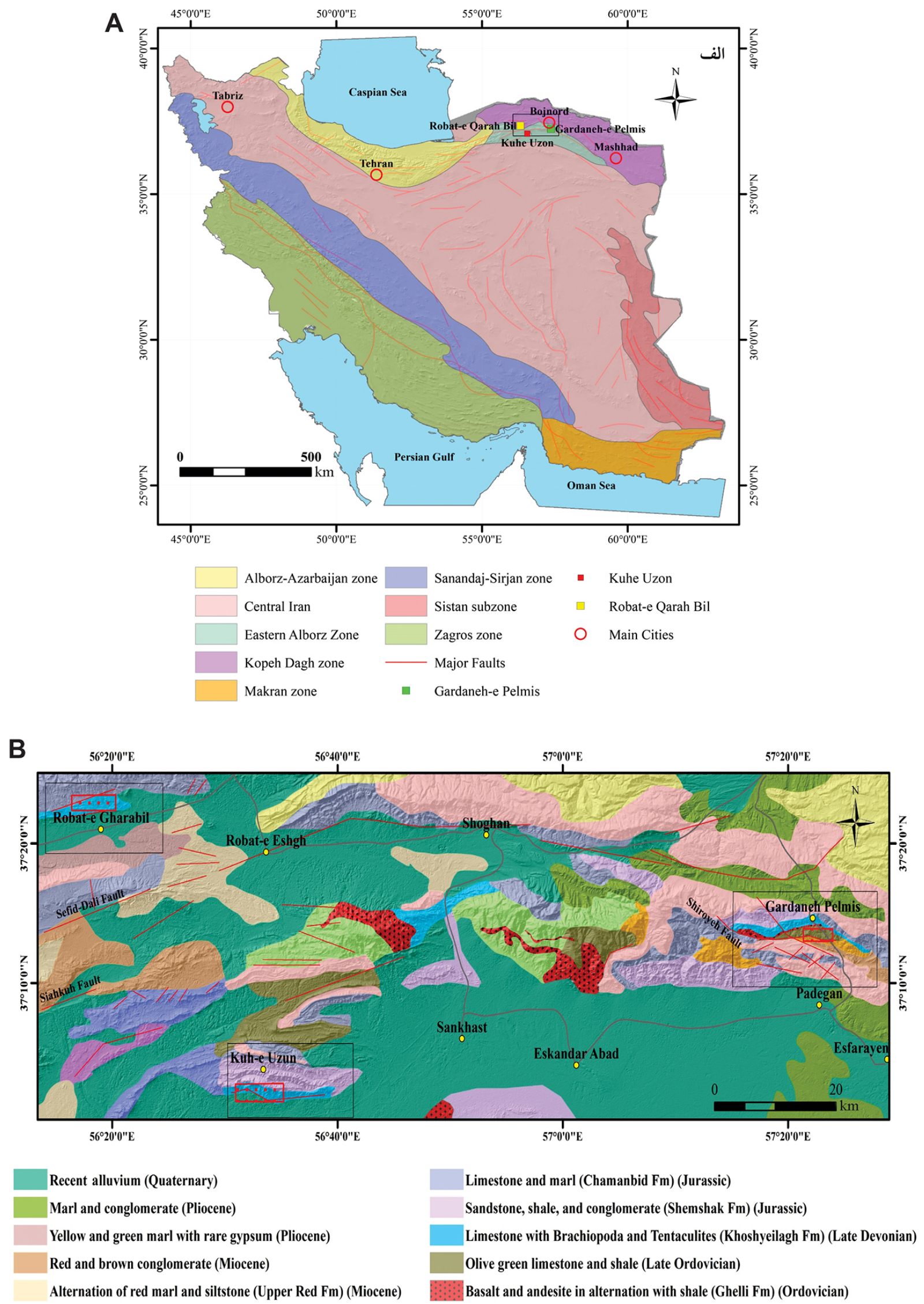

Figure 1. A, map showing main structural units of Iran (modified after Stocklin, 1968); B, the geological map of the studied areas representing different lithological units and geological features of the Robat-e Gharabil section (Salamati et al., 2001); Pelmis section (Mazaheri, 1999); Kuhe Ozon section (Soheilyand Sahandi, 1999). 


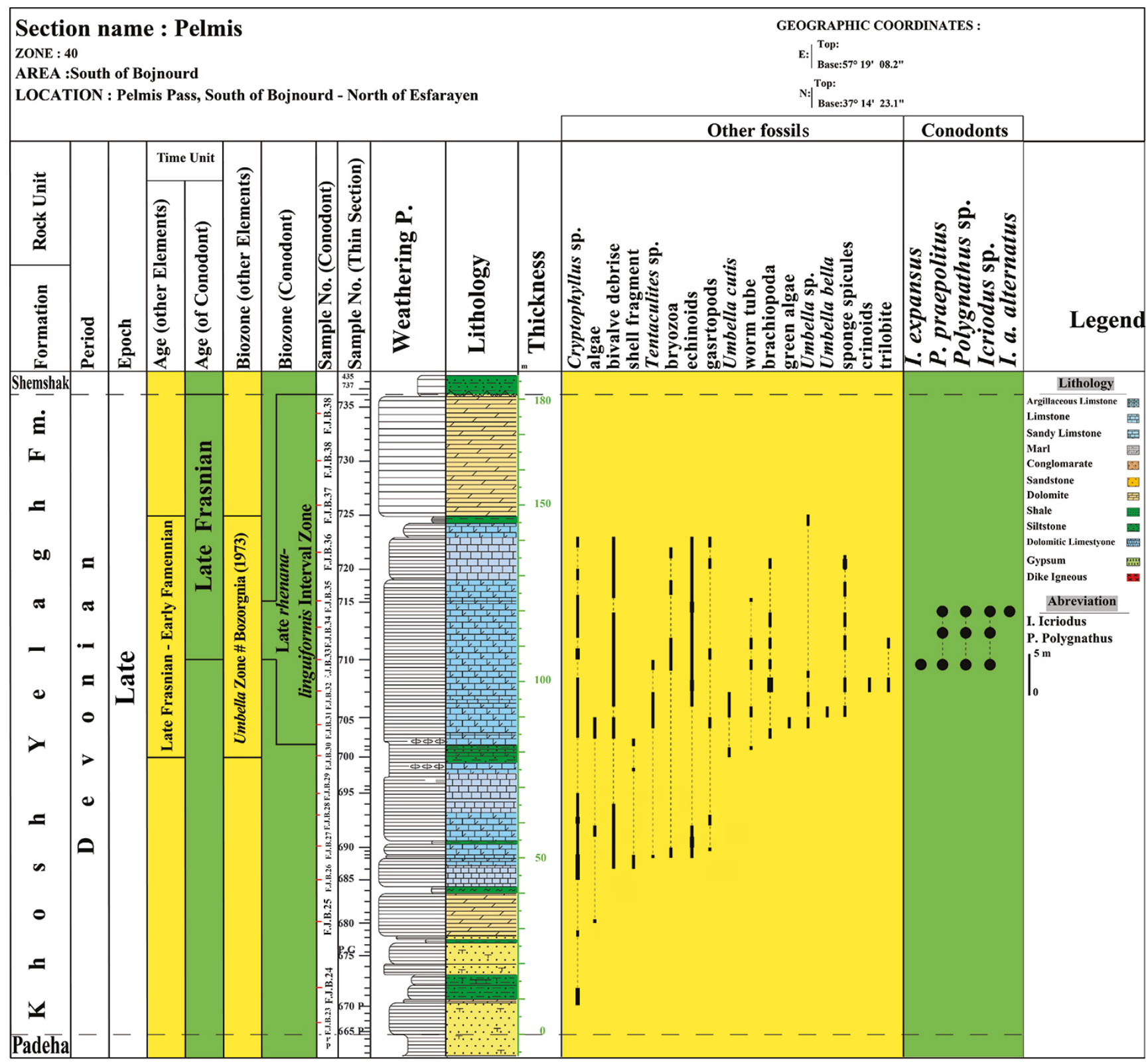

Figure 2. Distribution of conodont and other faunas and proposed ranges of biozones in the Pelmis section.

in the Khoshyeilagh Formation indicates a shallow marine environment, which is consistent with the lack of Famennian sediments in the Pelmis section, the minimum thickness of these deposits in Robat-e Qarehbil section, and reduced thickness of the Khoshyeilagh Formation in the Pelmis and Robat-e Qarehbil sections as compared to the Kuhe Ozon section and the type section.

\section{Non-conodont fossil assemblages in the study areas}

In the Pelmis section, the Khoshyeilagh Formation can be divided into three parts:

The lower part of the formation is $78 \mathrm{~m}$ thick (samples 665-699) and consists of limestone, dolomite, dolomitic sandstone, and siltstone containing Cryptophyllus sp., Tentaculites sp., echinoids, bivalve debris, algae, ostracods shell fragment, gastropods, and bryozoan fossil assemblages. Bozorgnia (1973) proposed the Umbella Zone and suggested Late Devonian age for this unit. The palynological findings of Ghavidel-Syooki \& Owens (2007) supported this dating.

The middle unit is $68 \mathrm{~m}$ thick (samples 700-725) and consists of limestone and dolomitic limestone. The fossil contents of this unit includes Umbellina bella, U. cutis, and $U$. sp. associated with Cryptophyllus sp., Tentaculites sp. (Figure 5), echinoids, bivalve debris, algae, ostracods shell fragments, gastropods, bryozoans, worm tubes, trilobites, crinoids, sponge spicules, green algae, and brachiopods. Bozorgnia (1973) included this unit into his Umbella Zone.

The upper part is $36 \mathrm{~m}$ thick, dolomitic with no fossil content (samples 726-737). Its age was estimated to be Late Devonian (Afshar-Harb, 1994). Evidence of the sea level drop 


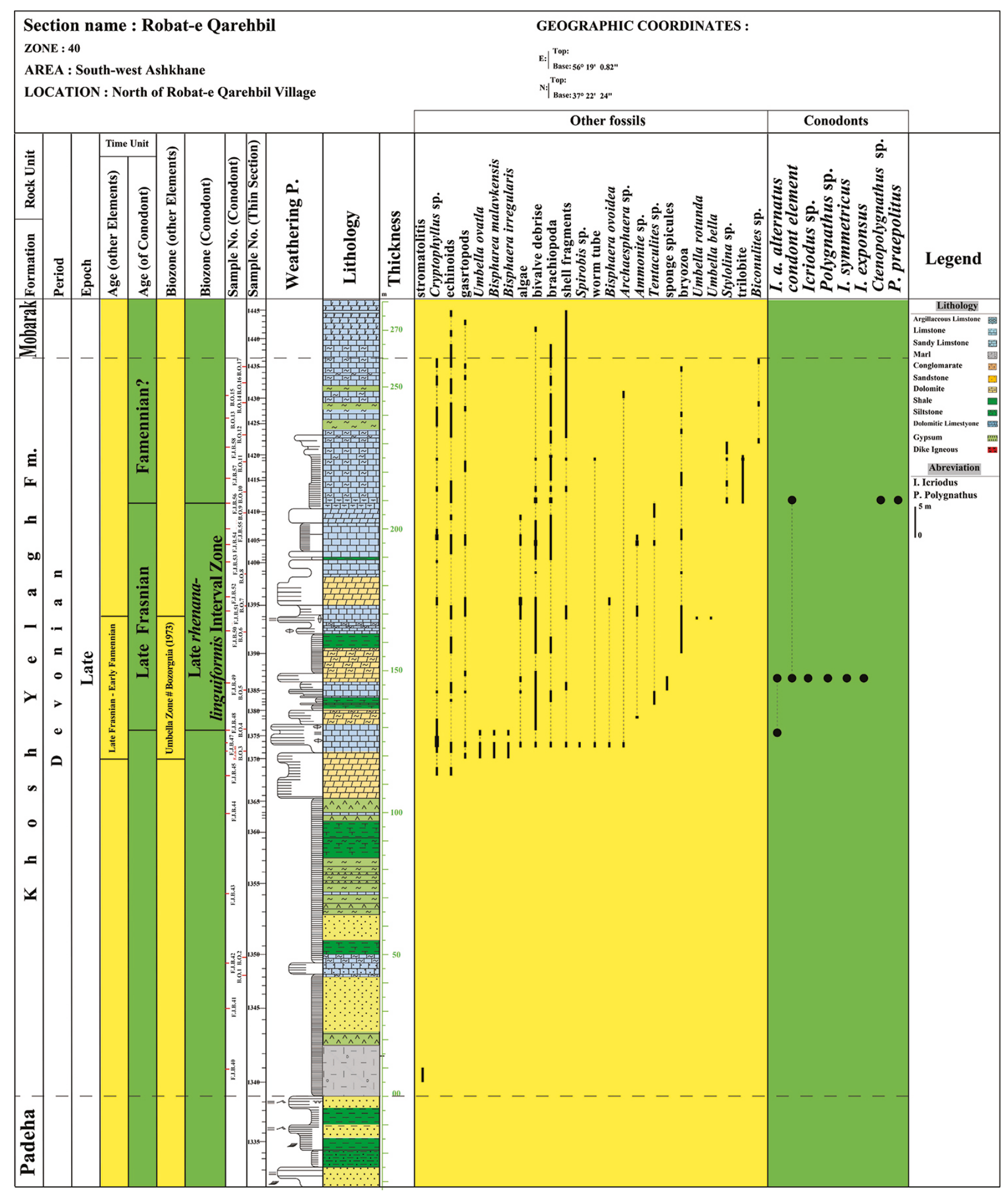

Figure 3. Distribution of conodont and other faunas and proposed ranges of biozones in the Robat-e Qarehbil section.

and erosion is observable in the upper parts of this section. The red laterite horizons are seen between the Khoshyeilagh and Shemshak Formations. Probably this part of the Khoshyeilagh Formation is upper Frasnian.
In the Robat-e Qarehbil section the Khoshyeilagh Formation can be divided into three parts:

The lower part includes $119 \mathrm{~m}$ (samples 1339-1369) of marl, gypsum, sandstone, siltstone, and dolomite. Only echinoids 


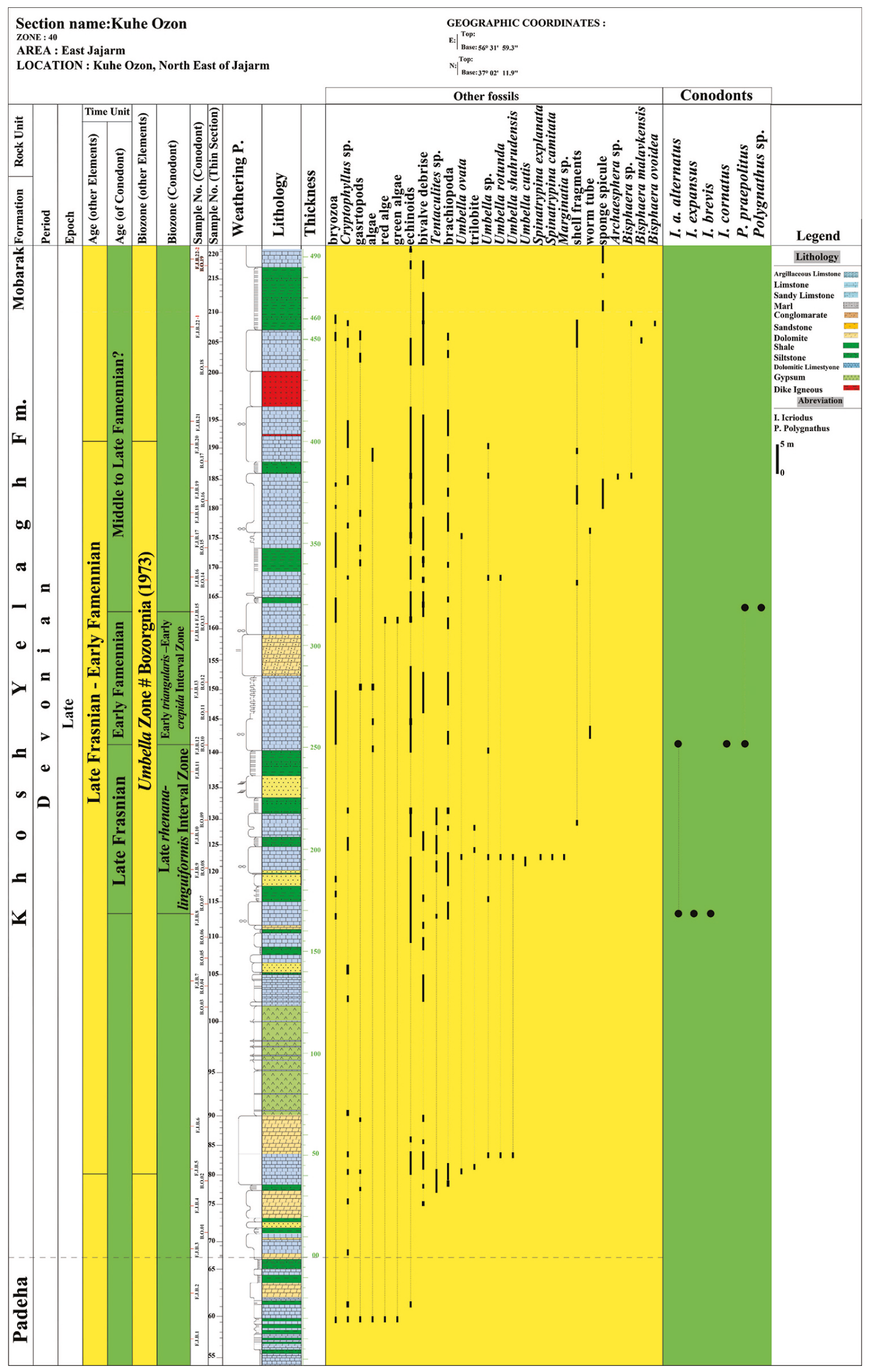

Figure 4. Distribution of conodont and other faunas and proposed ranges of biozones in the Kuhe Ozon section. 
and ostracods have been found there. However, some index miospore assemblages of the Upper Devonian were reported from this unit (Ghavidel-Syooki \& Owens, 2007).

The second part is $50 \mathrm{~m}$ thick (samples1370-1394) and consists of limestone, dolomite, and siltstone containing Cryptophyllus sp., Archaesphaera sp., Bisphaera ovoidea (Figure 6), Tentaculites sp., Umbellina bella, U. rotunda, $U$. ovata, Bisphaera irregularis, B. malavkensis, Microcornus sp., gastropods, echinoids, ostracods, algae, shell fragments, brachiopods, bivalve debris, worm tubes, bryozoans, sponge spicules, and ammonoids. The second part corresponds to the Bozorgnia's (1973) Upper Devonian Umbella Zone. Conodonts and sequence stratigraphy assessments supported the Late Frasnian age for this unit.

The third part is $91 \mathrm{~m}$ (samples 1397-1437) and consists of limestone and dolomite. The main fossils species of this part are Cryptophyllus sp., Tentaculites sp., Archaesphaera sp., Bisphaera ovoidea, algae, shell fragments, brachiopods, bivalve debris, worm tubes, bryozoans, ammonoids, Styliolina sp., Biconulites sp., trilobites, gastropods, echinoids, ostracods. Conodonts indicate early Famennian age of this unit (Figure 3).

In the Kuhe Ozon section the Khoshyeilagh Formation can be divided into three parts:

The lower part is $41 \mathrm{~m}$ thick (samples 66-79). Tentaculites sp. and Biconulites sp. are associated with ostracods, gastropods, trilobites, brachiopods, bivalves, worm tubes, bryozoans, and corals.

The second part represents the Umbella zone introduced by Bozorgnia (1973). This $359 \mathrm{~m}$ thick part (samples 80-191) contains Umbellina rotunda, $U$. shahrudensis, U. cutis, $U$. ovata, Tentaculites sp., Biconulites sp., and Earlandia sp., associated with echinoids, ostracods, brachiopods (Figure 7), gastropods, trilobites, worm tubes, bryozoans, and algae. This part is here dated as upper Frasnian to lower Famennian. The third part is $63 \mathrm{~m}$ thick (samples 192-210) and contains Archaesphaera sp., and Bisphaera sp. as the main fossil contents, and echinoids, ostracods, gastropods, trilobites, brachiopods, worm tubes, bryozoans, algae, and bivalves as the minor fossil content. Middle to late Famennian age is proposed for this unit (Figure 4).

\section{The comparison between biozones of the study areas with other parts of Iran}

The Upper Devonian (Frasnian) conodont biozones were reported by Ashouri (2006) in Khoshyeilagh Formation (northeast and Central Iran), and by Bahrami et al. (2014) in Sar-e-Ashk section (Central Iran) (Figure 8). The FrasnianFamennian age was attributed to the alternation of limestone and sandstone with interlayers of shale in the Hutk section (North of Kerman) (Gholamalian et al., 2011), Shotori ranges (Bahrami \& Yazdi, 2012), and eastern Alborz (Ashouri, 2006), which are comparable with biozones identified in our study areas (Figure 8).

The Frasnian Upper falsiovalis to punctata, the Lower hassi to jamieae, and the Lower to Upper rhenana biozones and the Famennian triangularis, crepida, and expansa to praesulcata biozones were recognized in the east of the
Taurides area in Turkey (Capkinoglu \& Gedik, 2000). These authors identified also Famennian conodonts of the Lower expansa and Middle expansa biozones in the northwest of Turkey. Ginter et al. (2011) reported similar biozones from Armenia. Our sections yielded different conodont assemblages, dominated with shallow marine Icriodus and Polygnathus instead of the pelagic species of Palmatolepis, which are the representative of deeper-water environments (Sandberg \& Dreesen, 1984) and have not been found in the Upper Devonian deposits of Iran. Associated fossils of benthic organisms are typical for shallow-water marine environments.

The fossil assemblages (Figures 9 and 10) and evaporitic deposits prove a warm tropical climate during the deposition of the studied formations. Comparing the fossil species identified in the study area with those from Zagros sedimentary basin, Central Iran, and other countries (e.g. Algeria, Libya, Morocco, Poland, Russia, and Australia), it can be concluded that this part of the Iranian plateau belonged to the northern part of the Gondwana continent in the Devonian period.

\section{The Frasnian-Famennian boundary in the studied sections}

In recent decades, many studies have been done on Frasnian-Famennian sequences in different parts of the world. The Coumiac section in southern France was identified as the type section of this boundary (Klapper et al., 1993; House et al., 2000). The Frasnian-Famennian boundary is known to be associated with the Kellwasser mass extinction and most of the studies on this boundary have been carried out in terms of the conodont standard biozonation (Ziegler \& Sandberg, 1990).

In this study, the biostratigraphy of the selected sections was based on conodont assemblages and associated benthic fossils such as umbellinas, tentaculites, and ostracods. As can be seen (Supplement 6), there is a relation between the sea level drop and the decrease in diversity at the Frasnian-Famennian boundary and a considerable increase after this point.

Furthermore, the presence of shallow marine sedimentary facies such as stromatolitic mudstones of tidal to lagoonal environments with dolomitic and siltstone composition represents significant shallowing in the basin in FrasnianFamennian boundary.

In Pelmis section, the shallowing continued to be shown by the presence of lateritic horizons at the top of the Khoshyeilagh Formation. During the early Famennian, the basin again experienced a deepening. A grainstone facies of bar setting and open marine deep-water facies such as bioclast spicule wackestone-packstone was established.

\section{CONCLUSIONS}

The paleontological studies on conodonts species and the faunas of the Khoshyeilagh Formation in the northeast of Iran led to the identification of seven conodont species and subspecies and 19 species of macro- and microfossils. Two conodont biozones, probably corresponding to the Frasnian Upper rhenana to linguiformis and the Famennian Lower 

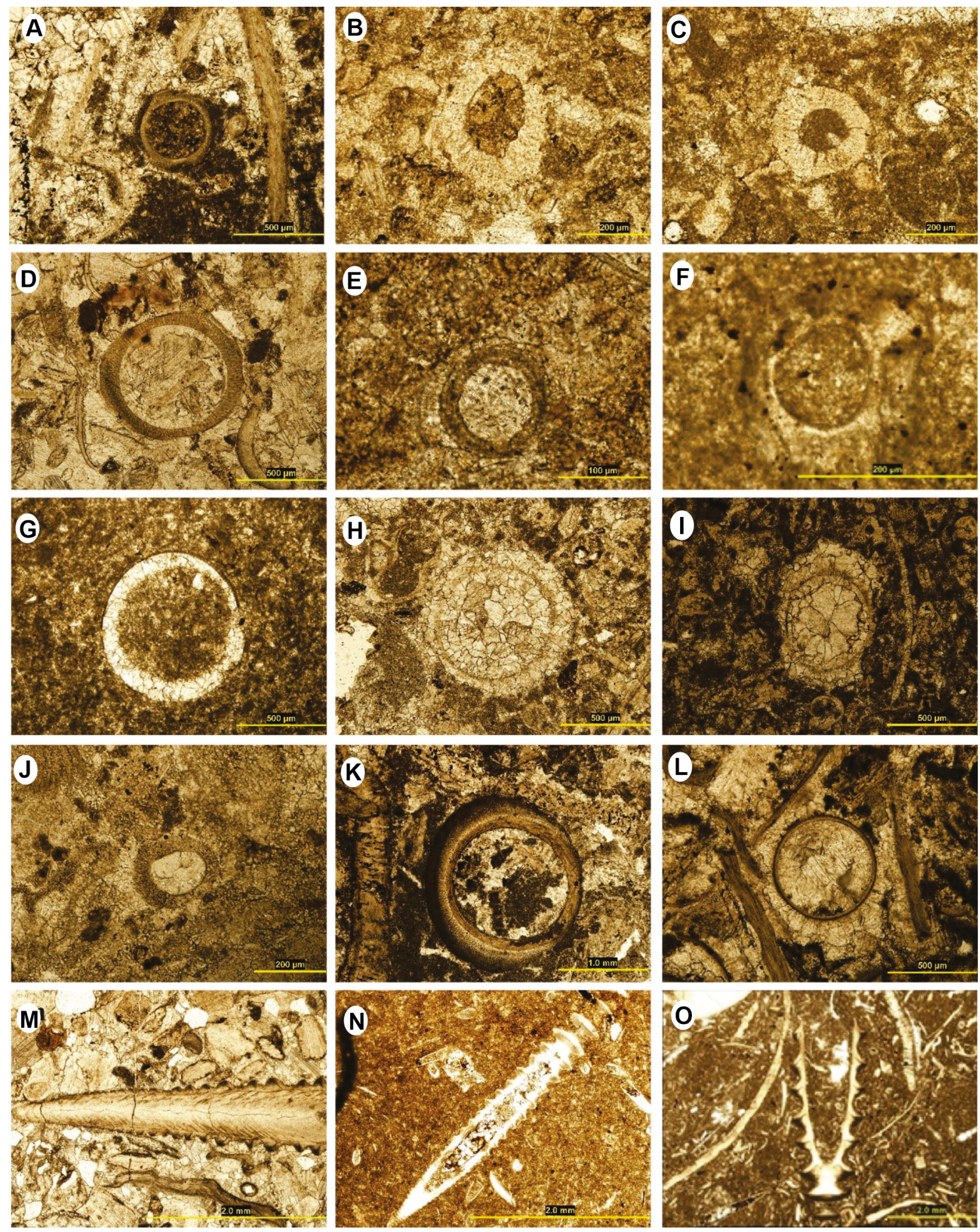

Figure 5. A, Umbellina ovata (Bozorgnia, 1973), sample 80; B, U. shhrudensis (Bozorgnia, 1973), sample 83; C, U. rotunda (Bykova, 1955), sample 83; D, Umbellina sp., sample 122; E, U. ovata (Bozorgnia, 1973), sample 700; F, U. cutis (Conil \& Lys, 1964), sample 706; G, Umbellina sp., sample 708; H, U. rotunda (Bykova, 1955), sample 1393; I, U. bella (Maslov, 1950), sample 1393; J, U. ovata (Bozorgnia, 1973), sample 175; K, U. ovata (Bozorgnia, 1973), sample 711; L, Archaesphaera sp., sample 1430; M-O, Tentaculites sp., samples 121, 1422, and 1384. Scale bars: A, D, G-I, L = 500 $\mu$ m; B-C, F, $\mathrm{J}=200 \mu \mathrm{m} ; \mathrm{E}=100 \mu \mathrm{m} ; \mathrm{K}=1 \mathrm{~mm} ; \mathrm{M}-\mathrm{N}=2 \mathrm{~mm}$. 

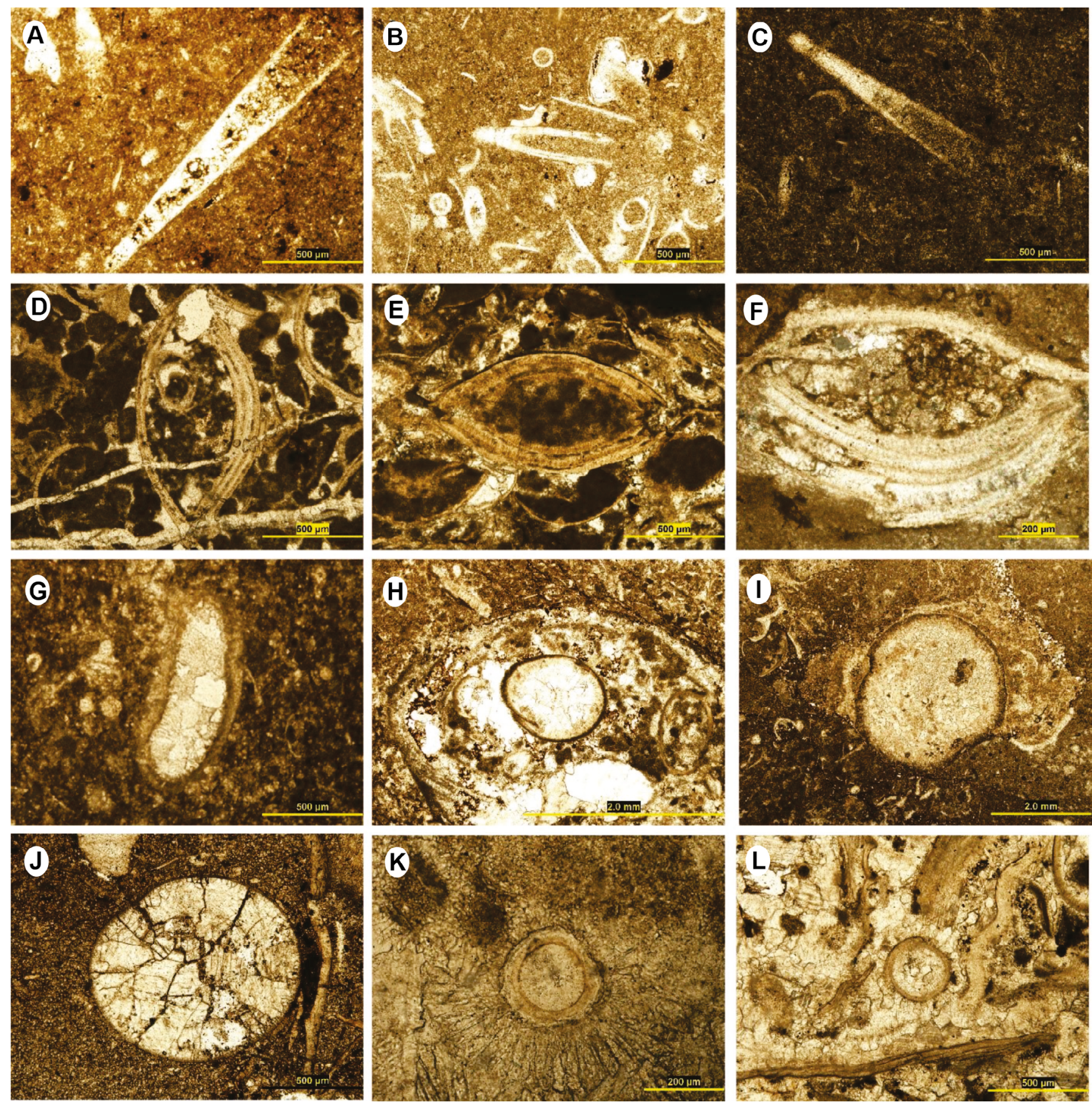

Figure 6. A-C, Styliolina sp., samples 1422, 1417 and 1415, cross section; D-F, Cryptophyllus sp., samples 90, 686 and 1374, cross section; G, Bisphaera elegans (Vissarionova, 1950) sample 1370; H-J, B. ovoidea (Conil \& Lys, 1964), samples 1373, 1395, and 208; K-L, Archaesphaera cf. minima (Suleimanov, 1945) samples 185 and 1430. Scale bars: A-E, G, J, L $=500 \mu \mathrm{m} ; \mathrm{F}, \mathrm{K}=200 \mu \mathrm{m} ; \mathrm{H}-\mathrm{I}=2 \mathrm{~mm}$.

triangularis to Lower crepida Palmatolepis-based standard zones, and one benthic fossil biozone, the Umbella Zone, were identified.

The comparison of the Upper Devonian deposits of the studied sections with other areas such as Central Iran, Western Alborz, Turkey, and Armenia shows that the Devonian sea deposited different conodont, macro-, and microfossils, depending on its local depth. Species typical of shallow settings, such as Icriodus and Polygnathus, have been found in the studied areas while the species related to pelagic environments, like Palmatolepis, have not been found. The conodonts, macro- and microfossils distribution patterns in three sections of the Khoshyeilagh Formation and the Gondwana sedimentary basins of Australia show similarities, suggesting the connection of the Iranian plateau with the Gondwana continent in the Devonian.

The identified conodonts and the other fossil assemblages such as umbellinas, tentaculites, and ostracods, the evidence 


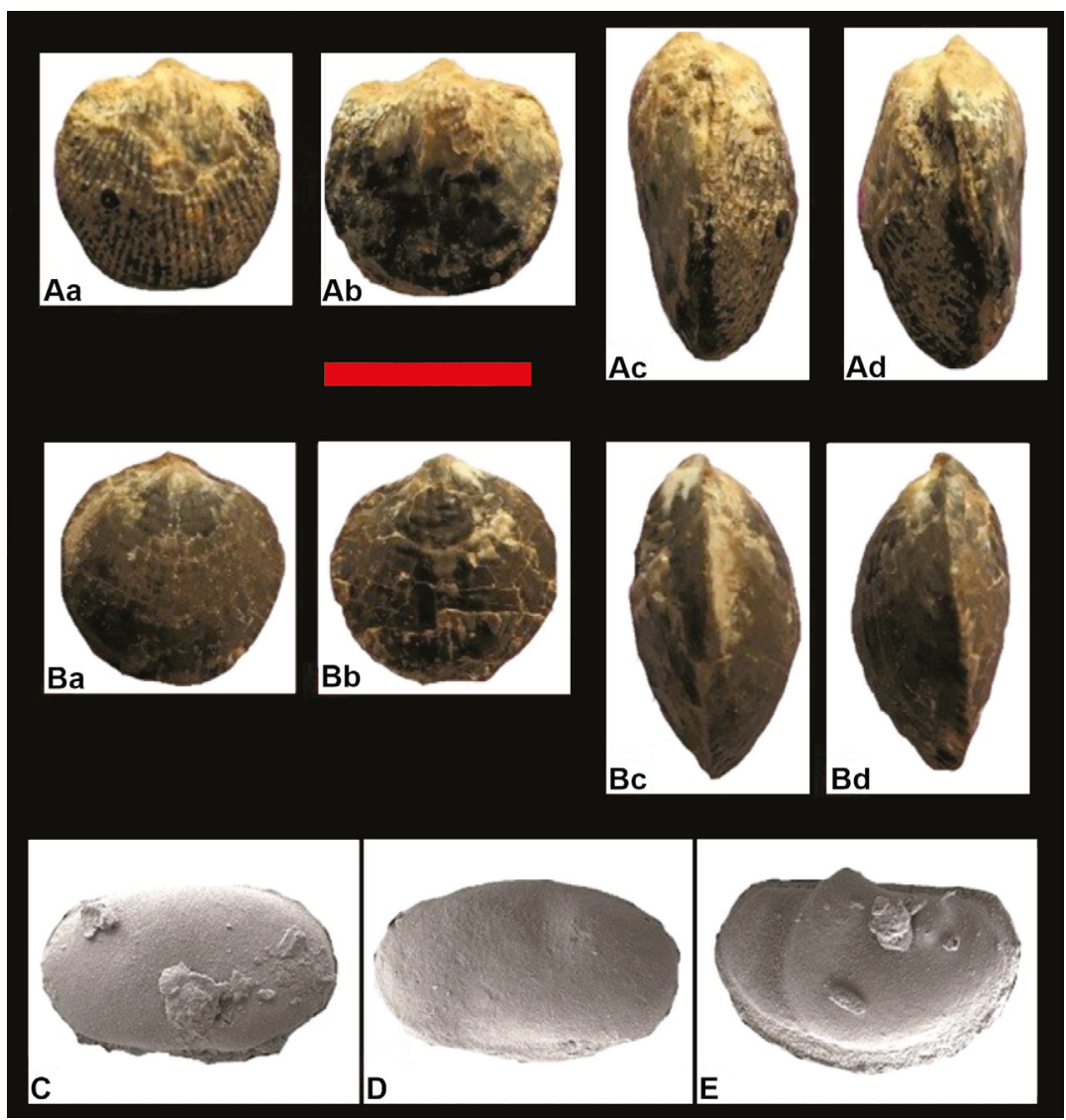

Figure 7. Aa-Ad, Spinatrypina explanata (Schlotheim, 1820), sample 165, x 1, Aa, pedicle valve view; Ab, brachial valve view; Ac, lateral view; Ad, posterior view. Ba-Bd, S. camitata (Copper, 1967b), sample 165, x 1, Ba, pedicle valve view; Bb, brachial valve view; Bc, lateral view; Bd, posterior view. C-D, Knoxiella cf. semilukiana (Egorov, 1950), samples F.J.B13 (x 246) and F.J.B.35 (x 280), carapace in right lateral view; E, Nodella faceta (Rozhdestvenskaya, 1972), samples F.J.B.13. Scale bar $=20 \mathrm{~mm}$.

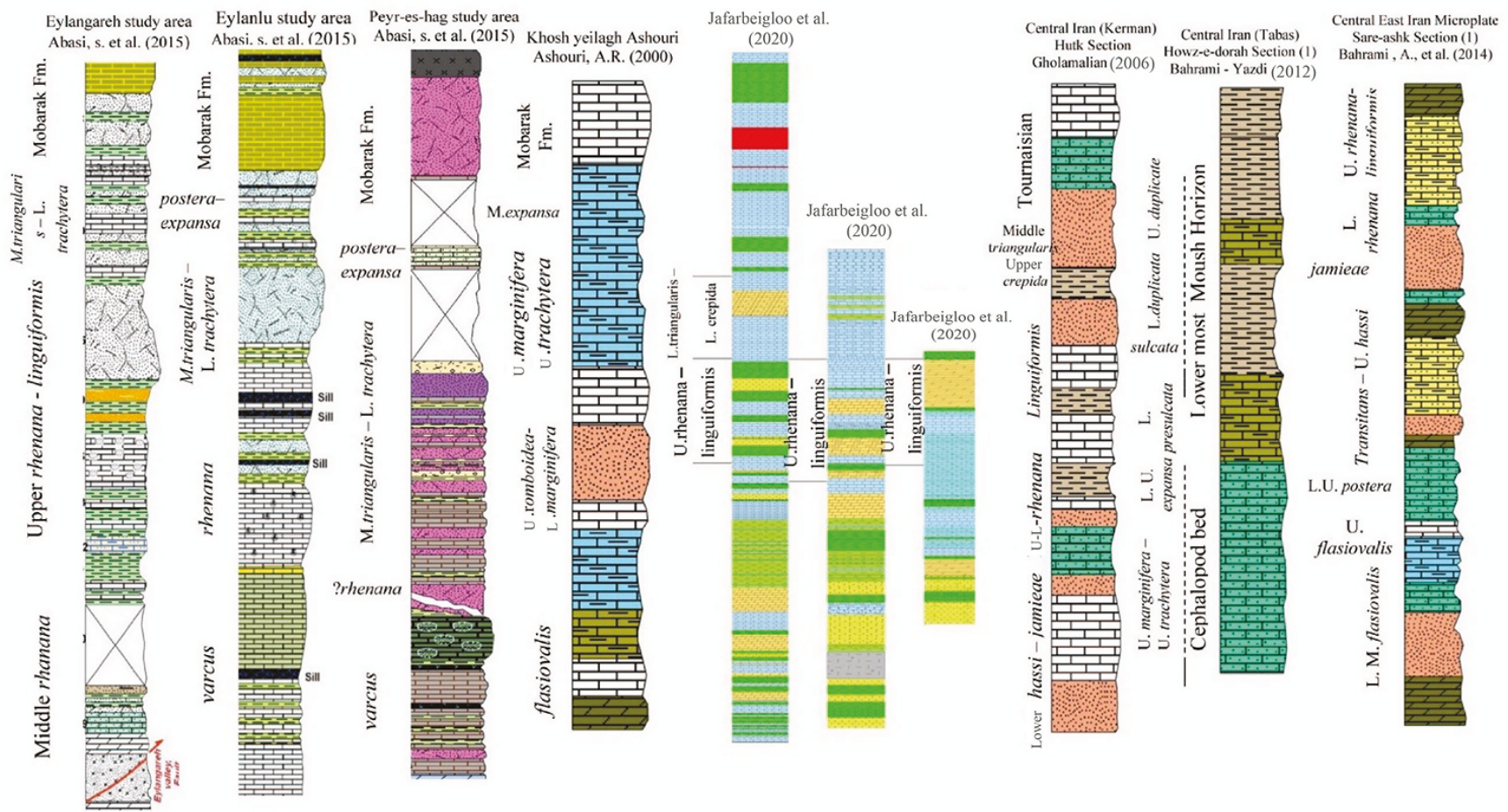

Figure 8. Rock columns and biozones of the Khoshyeilagh Formation in the study areas (Gardaneh-e Pelmis, Robat-e Qarehbil, and Kuhe Ozon sections) and the other Devonian sequences in NW Iran and Central Iran. 


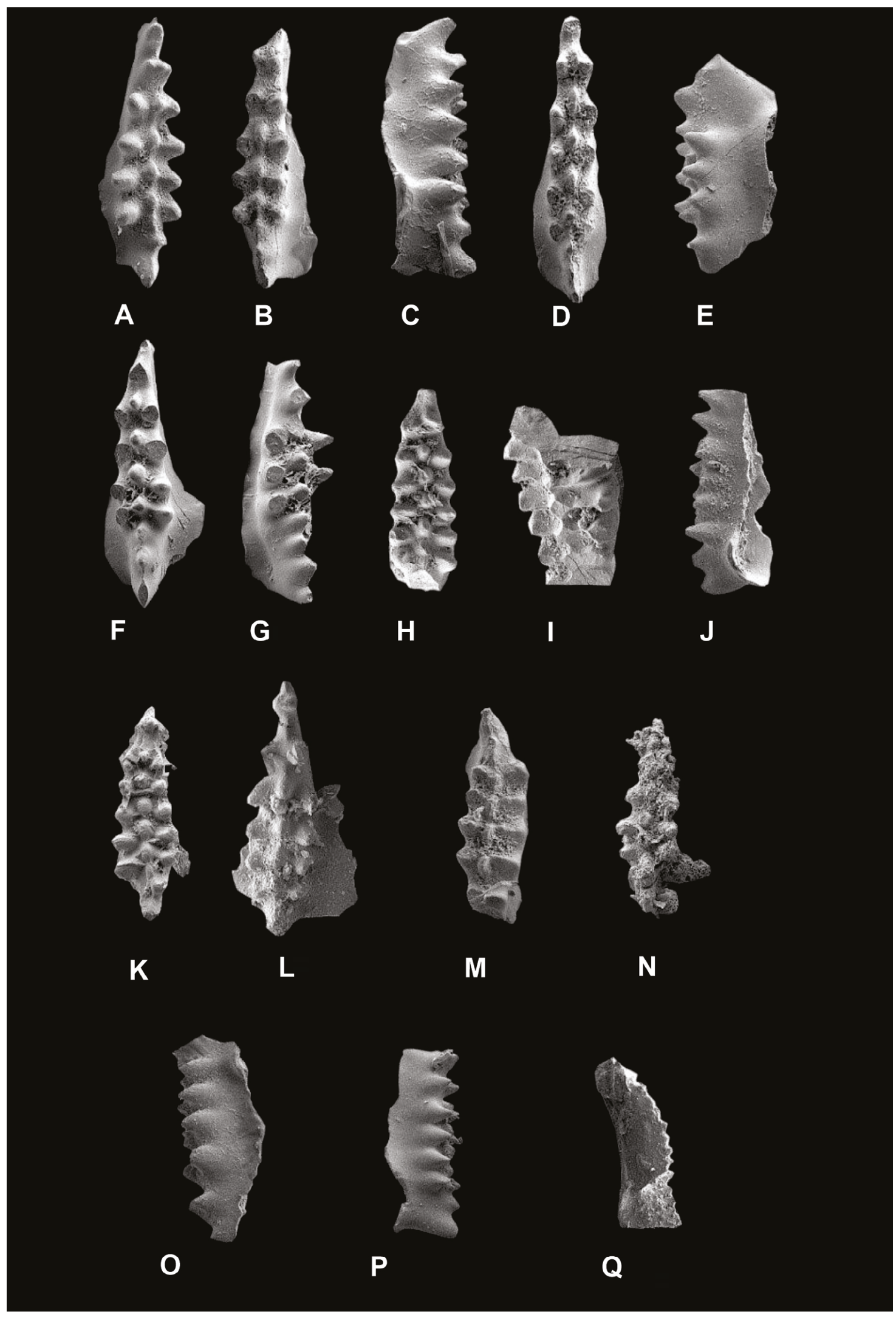

Figure 9. A-C, F, Icriodus cornutus Sannemann, 1955, A, upper view, 212x, sample F.J.B.48; B, upper view, 212x, sample F.J.B.48; C, lateral view, 212x, sample F.J.B.48; F, upper view, 316x, sample F.J.B.12. 4-5 \& 8-9). D-E, H-I, I. alternatus alternatus Branson \& Mehl, 1934. D, upper view, 246x, sample F.J.B.48; E, lateral view, 253x, sample F.J.B.12; H, upper view, 207x, sample F.J.B.48; I, lateral view, 233x, sample F.J.B.8. G, I. expansus Sandberg \& Dressen, 1984, lateral view, 303x, sample F.J.B.8. J-K, I. alternatus alternatus Branson \& Mehl, 1934. J, lower view, 260x, sample F.J.B.49; K, upper view, 204x, sample F.J.B.49. L-P, Icriodus sp. L, upper view, 294x, sample F.J.B.49; M, upper view, 257x, sample F.J.B.12; N, upper view, 245x, sample F.J.B.12; O, lateral view, 260x, sample F.J.B.12; P, Lateral view, 191x, sample F.J.B.12. Q, Polygnathus sp. (lower view, 278x, sample F.J.B.49). 


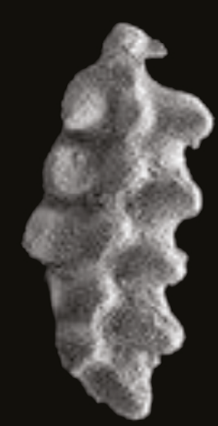

A

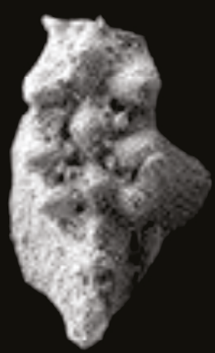

E

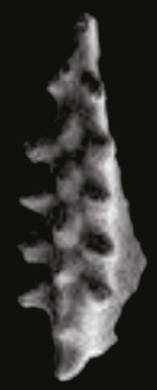

I

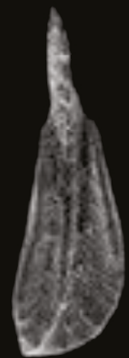

M

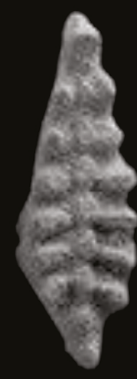

B

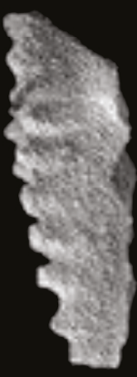

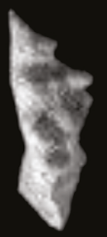

D

\section{C}
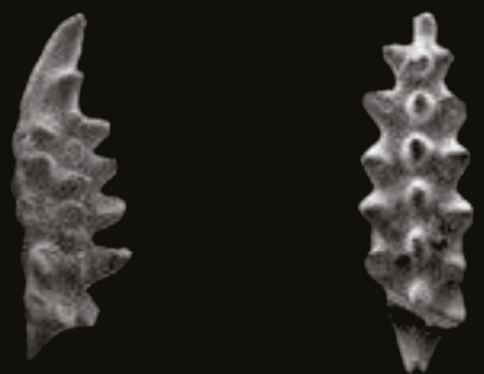

G

H
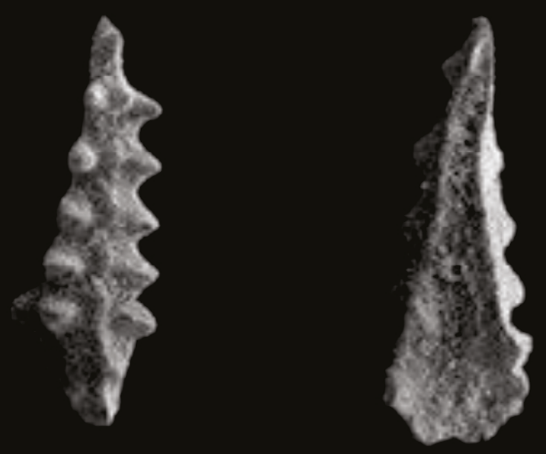

K

L

$$
\mathbf{J}
$$

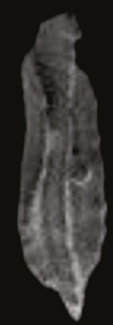

O

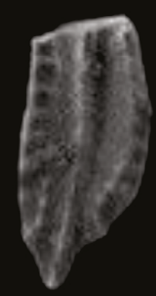

$\mathbf{P}$

Figure 10. A-E, Icriodus sp. A, upper view, 284x, sample F.J.B.33; B, upper view, 212x, sample F.J.B.33; C, lateral view, 178x, sample F.J.B.33; D, lateral view, 178x, sample F.J.B.34; E, upper view, 316x, sample F.J.B.34. F-H, Icriodus symmetricus Branson \& Mehl, 1934, F, upper view, 212x, sample F.J.B.49; G, upper view, 257x, sample F.J.B.49; H, side view, 260x, sample F.J.B.49. I-L, I. brevis Stauffer (1940), I, upper view, 212x, sample F.J.B.8; J, lower view, 207x, sample F.J.B.8; K, upper view, 234x, sample F.J.B.8; L, lower view, 220x, sample F.J.B.8. M-P, Ctenopolygnathus sp. Müller and Müller, (1957), M, upper view, 290x, sample F.J.B.56; N, lower view, 296x, sample F.J.B.56; O, upper view, 250x, sample F.J.B.56; P, upper view, $210 x$, sample F.J.B.56. 
related to sedimentology, stratigraphy, sequence stratigraphy, and sea level changes of these areas, and comparing these observations with the published global models enabled identification of the Frasnian-Famennian boundary in the studied sections.

The ages determined based on conodonts are consistent with the datings proposed by other researchers based on brachiopods and palynomorphs from similar sequences of the Khoshyeilagh Formation. The Devonian deposits of Iran show different lithologies because of forming in different tectonic settings, most likely related to thrust faults and formation of Horst-Graben settings.

\section{ACKNOWLEDGMENTS}

This study has been supported by the Islamic Azad University Science and Research Branch and the National Iranian Oil Company. The authors would like to express their deepest appreciations to the staff of these organizations. Furthermore, we would like to thank M. Bahrammanesh which helped us during the determination of different fossil species. The authors would also like to appreciate all reviewers for their hard work in order to edit and review the manuscript.

\section{REFERENCES}

Abbasi, S.; Hamdi, B. \& Majidifard, M.R. 2015. Biostratigraphy of Devonian successions in Illanghareh, Illanlu and Pir-Eshag sections, North West Iran, based on conodonts. Scientific Quarterly Journal of Geosciences, 25:209-226.

Afshar-Harb, A. 1979. The stratigraphy, tectonics, and petroleum geology of Kopet-Dagh region, Northern Iran. Petroleum Geology Section, Royal School of Mines, Imperial College London, Ph.D. thesis, 316 p.

Afshar-Harb, A. 1994. The geology of Kopet Dagh. Tehran, Geological Survey and Mineral Exploration of Iran, 275 p.

Ahmadzadeh Heravi, M. 1982. Brachiopods and conodonts of sediments in South of Bojnord and the obtained stratigraphic results. Journal of the College of Engineering, 45:57-73.

Aqanbati, A. 2007. Geology of Iran. Tehran, Publications of Geological Survey and Mineral Explorations of Iran, 582 p.

Ashouri, A.R. 2002. Palmatolepis (conodonta; Late Devonian) from the Tabas region, east Iran. Iranian International Journal of Science, 3:187-220.

Ashouri, A.R. 2004. Late Devonian and Middle-Late Devonian conodonts from eastern and northern Iran. Revista Española de Micropaleontología, 3:355-365.

Ashouri, A.R. 2006. Icriodus and Polygnathus (conodonts) from the Late Devonian of eastern Iran, and Middle-Late Devonian of northern Iran. Journal of Science, University of Tehran, 32:39-67.

Bahrami, A.; Corradini, C.; Over, D.J. \& Yazdi, M. 2013. Conodont biostratigraphy of the upper Frasnian-lower Famennian transitional deposits in the Shotori Range, Tabas area, CentralEast Iran Microplate. Bulletin of Geosciences, 88:369-388.

Bahrami, A.; Corradini, C. \& Yazdi, M. 2011a. Conodont biostratigraphy across the Devonian-Carboniferous boundary in the Shotori Range, Tabas area, central east Iran Microplate. Bollettino della Societa Paleontologica Italiana, 50:35-53.
Bahrami, A.; Gholamalian, H.; Corradini, C. \& Yazdi, M. 2011b. Upper Devonian conodont biostratigraphy of Shams Abad section, Kerman, Iran. Rivista Italiana di Paleontologia e Stratigrafia, 117:199-209.

Bahrami, A. \& Yazdi, M. 2012. Conodont biofacies of Devonian and Carboniferous boundary in central Iran (Ghale-kalaghu, Howz-e-Dorah 1 \& Howz-e-Dorah 2 sections) in comparison to the sections of European Alp basin and their relation with the Hangenberg bioevent. Journal of Stratigraphy and Sedimentology Researches, 28:59-80.

Bahrami, A.; Zamani, F.; Corradini, C.; Yazdi, M. \& Ameri, H. 2014. Late Devonian (Frasnian) conodonts from the Bahram Formation in the Sar-e-Ashk Section, Kerman Province, Central-East Iran Microplate. Bollettino della Societa Paleontologica Italiana, 53:179-188.

Berberian, M. \& King, G.C.P. 1981. Towards a paleogeography and tectonic evolution of Iran. Canadian Journal of Earth Sciences, 18:210-265.

Bozorgnia, F. 1973. Paleozoic Foraminifera Biostratigraphy of Central and East-Alborz Mountions, Iran. Nation Iranian Oil Company, Geological Laboratories, Publication 4, 185 p.

Brice, D.; Lafuste, J.; Lapparent, A.F.; De Pillet, J. \& Yassini, I. 1974. Étude de deux gisements paléozoiques (Silurien et Dévonien) de 1'Elbourz oriental (Iran). Annales de la Société Géologique de Belgique, 93:177-218.

Bultynck, P. 2003. Devonian Icriodontidae: biostratigraphy, classifica-tion and remarks on paleoecology and dispersal. Revista Española de Micropaleontologia, 35:295-314.

Bultynck, P. 2007. Limitations on the application of the Devonian standard conodont zonation. Geological Quarterly, 51:339-344.

Bykova, E.V. \& Polenova, E.N. 1955. Foraminifery, radiolarian i ostrakody devona Volgo-Uralskoi oblasti (Devonian foraminifera, radiolaria and ostracoda from the Volga-Ural region). Trudy VN1GRI, 87:1-141.

Capkinoglu, S. \& Gedik, I. 2000. Late Devonian conodont fauna of the Gumusali Formation, the eastern Taurides, Turkey. Turkish Journal of Earth Sciences, 9:69-89.

Doweld, A.B. 2014. Proposal to conserve the names Umbellina against Umbella and Umbellinaceae against Umbellaceae (fossil Charophyta). Taxon, 63:441-442. doi:10.12705/632.38

Dzik, J. 2002. Emergence and collapse of the Frasnian conodont and ammonoid communities in the Holy Cross Mountains, Poland. Acta Palaeontologica Polonica, 47:565-650.

Flügel, E. 2010. Microfacies of carbonate rocks: analysis, interpretation and application. $1^{\text {st }}$ ed. Berlin, Springer, $976 \mathrm{p}$.

Ghavidel-Syooki, M. \& Owens, B. 2007. Palynostratigraphy and palaeogeography of the Padeha, Khoshyeilagh and Mobarak formations in the eastern Alborz Range (Kopeh-Dagh region), northeastern Iran. Revue de Micropaléontologie, 50:129-144. doi:10.1016/j.revmic.2007.01.004

Gholamalian, H. 2006. Biostratigraphy of Late Devonian sequence in Hutk section (North of Kerman) based on conodonts. Geosciences Scientific Quarterly Journal, 15:94-101.

Gholamalian, H. 2007. Conodont biostratigraphy of the FrasnianFamennian boundary in the Esfahan and Tabas areas, central Iran. Geological Quarterly, 51:453-476.

Gholamalian, H.; Hairapetian, V.; Barfehei, N.; Mangelian, S. \& Faridi, P. 2013. Givetian-Frasnian boundary conodonts from Kerman Province, Central Iran. Rivista Italiana di Paleontologia e Stratigrafia, 119:133-146.

Gholamalian, H.; Hosseini-Nezhad, S.M.; Khosravi, Z. \& TurkzadehMahani, I. 2011. Late Devonian conodonts from Baghin section, 
west of Kerman. Geosciences Scientific Quarterly Journal, 21:165-172.

Gholamalian, H. \& Kebriaei, M.R. 2008. Late Devonian conodonts from the Hojedk section, Kerman Province, Southeastern Iran. Rivista Italiana di Paleontologia e Stratigrafia, 114:171-181.

Ginter, M.; Hairopetian, V. \& Grigorian, A. 2011. Chondrichthyan microfossils from the Famennian and Tournaisian of Armenia. Acta Geologica Polonica, 61:153-173.

Hamdi, B. \& Janvier, P. 1981. Some conodonts and fish remains from Lower Devonian, northeast of Shahrud, Iran. Geological Survey of Iran, Report, 49:195-213.

House, M.R.; Becker, R.T.; Feist, R.; Girard, C. \& Klapper, G. 2000. The Frasnian/Famennian boundary GSSP at Coumiac, southern France. Courier Forschungsinstitut Senckenberg, 225:59-75.

Jafarbeigloo, F.; Majidifard, M.R.; Hamdi, B.; Asghari, A. \& Arian, M. 2020. Depositional environment and sequence stratigraphy of the Khoshyeilagh Formation in Bojnourd and Jajarm (NE Iran). Turkish Journal of Earth Sciences, 29:853-877. doi:10.3906/ yer-1811-12

Ji, Q. \& Ziegler, W. 1993. The Lali section: an excellent reference section for Late Devonian in south China. Courier Forschungsinstitut Senckenberg, 157:1-183.

Klapper, G.; Feist, R.; Becker, R.T. \& House, M.R. 1993. Definition of the Frasnian/Famennian stage boundary. Episodes, 16:433441.

Mamet, B.L. Sur les Umbellaceae. Canadian Journal of Earth Sciences, 7:1164-1171.

McGhee, G.R. 2001. The 'multiple impacts hypothesis' for mass extinction: a comparison of the Late Devonian and the late Eocene. Palaeogeography, Paleoclimatology, Paleoecology, 176:47-58. doi:10.1016/S0031-0182(01)00325-X

Nabavi, M.H. 1976. A Preface to Iran's Geology. Tehran, Geological Survey and Mineral Exploration of Iran, 109 p.

Ovnatanova, N.S. \& Kononova, L.I. 2001. Conodonts and Upper Devonian (Frasnian) biostratigraphy of central regions of Russian platform. Courier Forschungsinstitut Senckenberg, 233:1-115.

Peck, R.E. 1974. On the systematic position of the umbellids. Journal of Paleontology, 48:409-412.
Sandberg, C.A. \& Dreesen, R. 1984. Late Devonian icriodontid biofacies models and alternate shallow-water conodont zonation. Geological Society of America Special Paper, 196:143-178.

Sandberg, C.A.; Ziegler, W.; Dreesen, R. \& Butler, J.L. 1988. Late Frasnian mass extinction: conodont event stratigraphy, global changes, ans possible causes. CFS Courier Forschungsinstitut Senckenberg, 102:263-307.

Stocklin, J. 1968. Structural history and tectonics of Iran; a review. American Association of Petroleum Geologist Bulletin, 52:1229-1258 .

Sweet, W.C. 1988. The Conodonta: morphology, taxonomy, paleoecology, and evolutionary history of a long-extinct animal phylum. Oxford Monographs on Geology and Geophysics, No. 10. Oxford, Clarendon Press, $224 \mathrm{p}$.

Weddige, K. 1984a. Externally controlled late Paleozoic events of the Iran Plate. Neues Jahrbuch für Geologie und Paläontologie, 168:278-286.

Weddige, K. 1984b. Zur Stratigraphie und Paläogeographie des Devons und Karbons von NE Iran. Senckenbergiana Lethaea, 65:179-223.

Wendt, J.; Kaufmann, B.; Belka, Z.; Farsan, N. \& Karimi Bavandpur, A. 2002. Devonian/Lower Carboniferous stratigraphy, facies patterns and palaeogeography of Iran, Part I. Northern and central Iran. Acta Geologica Polonica, 55:31-97.

Ziegler, W. 1975. Catalogue of Conodonts. Stuttgart, Schweizerbart'sche Verlagsbuchhandlung, $404 \mathrm{p}$.

Ziegler, W. 1981. Catalogue of Conodonts. Stuttgart, Schweizerbart'sche Verlagsbuchhandlung, $445 \mathrm{p}$.

Ziegler, W. \& Sandberg, C.A. 1990. Late Devonian standard conodont zonation. Courier Forschungsinstitut Senckenberg, 121:1-115.

Ziegler, W. \& Sandberg, C.A. 2000. Utility of palmatolepids and icriodonids in recognizing Upper Devonian series, stages and possible substage boundaries. Courier Forschungsinstitut Senckenberg, 225:335-337.

Received in 26 February, 2020; accepted in 29 October, 2020. 